\title{
Tantrum Behavior Modification for Autistic Student at Secondary School Using Social Stories Technique
}

\author{
Noriah binti Sha'arania ${ }^{a}$ Mohd Mokhtar Tahar ${ }^{b}$ \\ aSekolah Menengah Kebangsaan Malim, 75250 Bertam Malim, Melaka, Malaysia \\ bUniversiti Kebangsaan Malaysia, 43600 Bangi, Selangor, Malaysia. \\ E-mail : noriahshaarani@gmail.com
}

\begin{abstract}
Autistic children have some social problems including weakness in bilateral interaction, communication problems and lack of imagination. The objectives of this study were to examine the effectiveness of social stories technique in reducing the duration of a student autistic tantrum and elimination of the problem tantrum. This study is a case study that builds quantitative behavior classical conditioning theory expounded by Ivan Pavlov and combined with the ADDIE Model. Observations carried out over a period of 20 days to see the effectiveness of social stories technique for changing the negative behavior of autistic students studying in a secondary school. The method of A-B where A represents the baseline phase and B-phase intervention represents. Social stories read to sample every day before the teaching begins within 10 minutes. The results of this study found that social stories technique successfully reduced the tantrum behavior study. However, tantrum behavior is still failing to be completely eliminated, but there is a significant reduction of the behavior. Through this study, it was found the use of social stories can reduce negative behaviors in autistic teenager. It is hoped that this study can serve as a guide and ideas for teachers to diversify the techniques to modify negative behavior among pupils in special education. We hope this study can be uplifting and inspiring teachers that negative behavior autistic students can be changed with the right technique.
\end{abstract}

Keywords: behavior modification, autistic, tantrum, social stories technique

Autistic students are those students who often falls behind in terms of communication, social and cognitive skills than their peers. Most of them show difficulties in verbal and nonverbal communication, social interaction and in doing activities or playing with their friends (Autism Society of America, 2006). As a result, according to Rubina and Kripa (2011), the failure in social and communication development has caused difficulties in such areas. This difficulty has led to the existence of negative behavior towards the autism. These behavior or problem behaviors refer to situations in which features such as violent behavior or being passive for a long time, causing the performance of children's learning is affected (Saadah et al., 2008). One of the negative behaviors in question and the focus of this study is the tantrum. According to Rahmah (2010) without a proper solution, tantrum will cause harm to an autistic person, including hurting themselves and others. Incontrollable tantrum behaviors among the autistics are shown as crying, shouting, rolling over the floor as well as kicking things around themselves.

The usage of social stories techniques in order to change the autistic children behavior was introduced by Gray (1995) as a teaching aid to social skills. Social stories are short descriptions of a particular situation, event or activity, which include specific information about what to expect in that situation and why. The technique were introduced by Gray (1995) which consists three steps, (1) story reading, (2) comprehension and (3) role playing. A study was conducted by Chan and O'Reilly (2008) has proven that this technique has successfully changed the behaviors of two autistics students under an inclusive classroom without the presence of their counselor during the class in session. Another study by Shari, Brenda \& Judith (1998) found out that social stories technique were able to reduce the tantrum behavior of an autistic student. The study was conducted by using illustrations intended to the autistic student in a form of giving instructions, options and rational explanation of the purpose of changing a negative behavior.

According to Nurfarhana and Normaliza (2015) in their study, the element of storytelling through oral aspects has a positive impact and is able to act as a technique of a lifelong learning for the autistics. According to Liew and Ali (2008), the intervention program is a process of providing services, education and support to children who are at risk or are experiencing delays in physical and mental development that will affect or hinder learning process. This study was conducted to examine the effectiveness of using social stories to change negative behaviors in autistic children. 
Figure 1. A conceptual framework that uses a combination of modification of the Theory of Classical Conditioning by Pavlov (in Suppiah et al., 2008), ADDIE Model by (Michael, 2003) and A-B Design study that inspired by Thomas (2005)

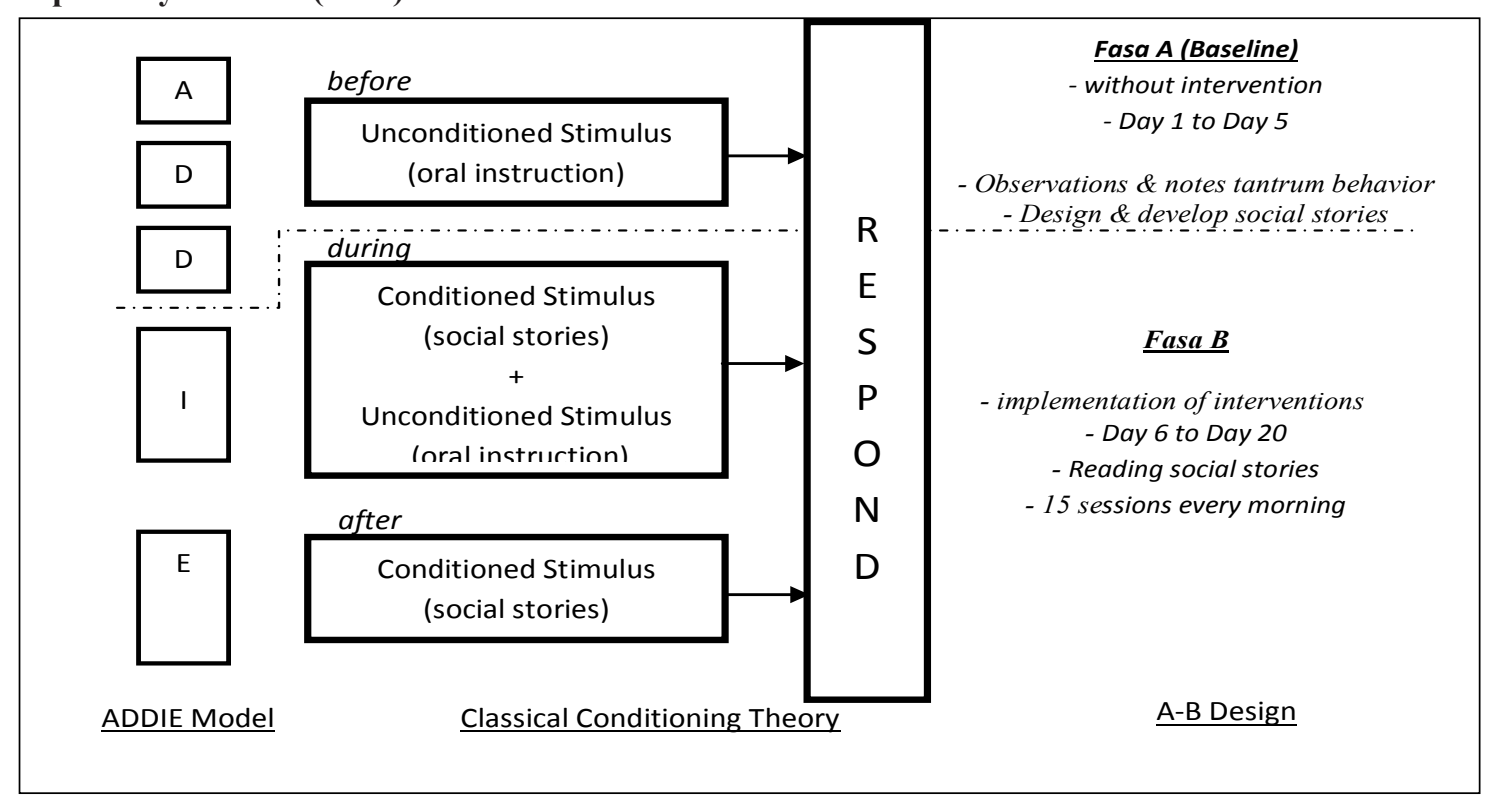

According to Chan and O'Reilly (2008), a social story is one of the effective ways to work on a particular understanding of autistic children whom are facing problems with communication and thus changing their behavior and promote effective teaching and learning.

Therefore, behavior management is an important aspect that should be known and understood by each special education teacher. According to Noor Aini and Norhafizah (2015), teachers are able to cope with the students' behavior provided with a behavior management module. Teachers who are facing with such issues will be burdened by mood disorders and this will hinder them from a good teaching performance.

This study is basically based on behavioral theory, namely the theory of classical conditioning Pavlov taken from the book of Suppiah et al. (2008). This theory states that the stimulus provided will create the response. The stimulus in this study refers to the reading of the social story to a sample study, while the response was the elimination of tantrum behavior that is expected from the sample. The social stories were created by using the ADDIE model by Michael (2003). This model is commonly used by researchers in the development of software-based computers in teaching and learning in schools. However, the five major phases in this model is applied based on a logical modification in order to construct the sets of appropriate social stories and the sample capabilities in this study. The phases involved are analysis, design, development, implementation and evaluation. The studies by Baharuddin et al. (2002) in Rafiza and Maryam (2013) had pointed out that the construction of a software that does not meet any of instructional design is still able to produce good software in terms of graphics, technology and visual, but it may not be necessarily improve the quality of learning. Figure 1 is a conceptual framework of this study which is using the theory of classical conditioning, Ivan Pavlov, (1904), combined with the ADDIE Model Michael (2003) and the study design A-B by Thomas (2005).

The autistic children can actually see and hear. However, the mental disability they face had caused them difficulties to understand and interpret the information obtained. According to Adriana (2007) in his study, normal children who are four years old are generally already able to understand the thoughts, the instructions and the feelings of others, but for someone with autism, to understand a matter is very difficult or "mindblindness". The objectives of this study are: (i) the effect of social story to the reduction of the period of tantrum behaviors in autistic student; (ii) the effect of social stories in the elimination of tantrum behavior in autistic student.

This is because the tantrum behavior can interfere with the process of teaching and learning in schools. Hastings and Brown (2002) in a study by Wendy et al. (2007) have stated that the teachers' emotion can also be affected as a result of the challenging behavior of ASD (Autism Spectrum Disorders). 
Figure 2. Data Collection Form

\begin{tabular}{|c|c|c|c|c|c|}
\hline \multicolumn{6}{|c|}{$\begin{array}{l}\text { Name: Zhen } \\
\text { Environment : PPKI, Secondary school } \\
\text { Expected behavior : } \\
\text { 1. Reduce in tantrum frequency } \\
\text { 2. Reduction/ elimination of tantrum }\end{array}$} \\
\hline Phase & Date & Start & End & $\begin{array}{l}\text { Duration } \\
\text { (minute) }\end{array}$ & $\begin{array}{c}\text { Amount } \\
\text { of } \\
\text { tantrum } \\
\text { (week) }\end{array}$ \\
\hline \multirow{5}{*}{ Phase A } & $170 \mathrm{at}$ & 1050 & 1115 & 25 & \multirow{5}{*}{$w h=-k 1$} \\
\hline & $180 \mathrm{dt}$ & - & - & - & \\
\hline & $190 \mathrm{dt}$ & 1105 & 1145 & 40 & \\
\hline & $200 \mathrm{ct}$ & 1145 & 1210 & 25 & \\
\hline & $2100 t$ & - & - & - & \\
\hline \multirow{15}{*}{ Phase B } & $2600 t$ & 1135 & 1150 & 15 & \multirow{5}{*}{4} \\
\hline & $2700 t$ & 1055 & 1105 & 10 & \\
\hline & $2 \mathrm{Nov}$ & - & - & - & \\
\hline & $3 \mathrm{Nov}$ & 1045 & 1050 & 5 & \\
\hline & $4 \mathrm{Nov}$ & 1130 & 1132 & 2 & \\
\hline & $7 \mathrm{Nov}$ & 9.15 & 916 & 1 & \multirow{5}{*}{2} \\
\hline & $8 \mathrm{Nov}$ & - & - & - & \\
\hline & 9Nov & 1140 & 1141 & 1 & \\
\hline & $10 \mathrm{Nov}$ & - & - & - & \\
\hline & $11 \mathrm{Nov}$ & - & - & - & \\
\hline & $14 \mathrm{Nov}$ & 1040 & 10.41 & 1 & \multirow{5}{*}{1} \\
\hline & $15 \mathrm{Nov}$ & - & - & - & \\
\hline & $16 \mathrm{Nov}$ & - & - & - & \\
\hline & $17 \mathrm{Nov}$ & - & - & - & \\
\hline & $18 \mathrm{NbV}$ & - & - & - & \\
\hline
\end{tabular}

\section{METHOD}

This study is a quantitative case study with singlesubject method, aiming to examine the effectiveness of interventions through social stories to reduce the sample's negative behaviors. Data collected through a 20-day observation (according to the sample school attendance) and loaded into the data collection form "Period" (Thomas, 2005) that has been modified.

Observations made during the current session would take place with the conformity assessment for the A-B was also an idea by Thomas (2005) in his Behavior Management book : (i) Phase A: The first baseline with the recorded data sample tantrum behavior studies performed within 5 days after the study began; (ii) Phase B: The implementation of the intervention using social stories to a sample of 15 sessions conducted on each morning. Storytelling will take place in the last 10 minutes. Social stories read by the sample itself monitored by the researchers and the aid from other teachers. The social stories are on display in the classroom which accommodates the pupils. At this stage, the process of collecting data on the tantrum was proceeding.

The selection of the samples is based on research sampling purposive sampling (Noraini, 2010). The sample is an autistic student who has trouble in communicating and learning in Special Education Integration Programme (PPKI) in a secondary school in
Melaka. The sample was an 18-year-old male student. These students have a variety of negative behavior problems, but the focus in this study is the tantrum occurring almost every day and takes a relatively long period of time to calm him down again. Therefore, the sample is given six social stories for the purpose of intervention on behavior.

\section{FINDINGS AND DISCUSSION}

Observations were made by the researchers towards the sample during the school session. This includes the learning session and breaks. This method is carried out to see frequency of tantrum each time these negative behaviors do occur and to identify any elimination of tantrum behavior. Observations were made on each item that is targeted towards the sample and listed in the Data Collection Form (Figure 2) that has been modified from the idea of Thomas (2005) in his book Behavior Management. This record result is presented in the form of a graph (Graph 1) for the convenience of researchers to analyze and provide convenience to the reader. The findings are as follows:

Social stories technique is effective in reduction of the period of tantrum behaviors in autistic student. This can be seen since the intervention was introduced and implemented, it was found that the applicable period

tantrum began to decline from the first day of a social story was read to the last day of the implementation. Any behavior that indicates the beginning of an impending tantrum (as is the norm in force) will continue to be noted and considered as a data or the first minutes of the negative treatment of the sample studied. The tantrum happened for 25 minutes on the first day before the social story was read. On the second day, there were no tantrum incident happened. However, the sample again throwing tantrum within 40 minutes on the third day of the study took place. The next day tantrum occurs within 25 minutes and there were no tantrums made on the fifth day of the last day before the sample is introduced to the intervention of social stories. During the intervention was carried out, it appears that there were tantrum incidents occurred during the 15 minutes on the first day of the social story was read. On the second day of this phase, there were still tantrum occurs within the 10 minutes. On the fourth day, the tantrums once again occurred within 5 minutes and began to decrease on the fifth day for 2 minutes. There were no tantrums incident occurred on the third, seventh, ninth and tenth in the intervention phase was conducted. In the last week of the study and intervention was carried out, the sample only threw tantrum for once which lasted only one minute.

Social stories do not eliminate a tantrum behavior in autistic children but can virtually eliminate the juvenile tantrums. 


\section{Graph 1. Time frame analysis results reduction tantrum and reduction / elimination tantrum behaviors}

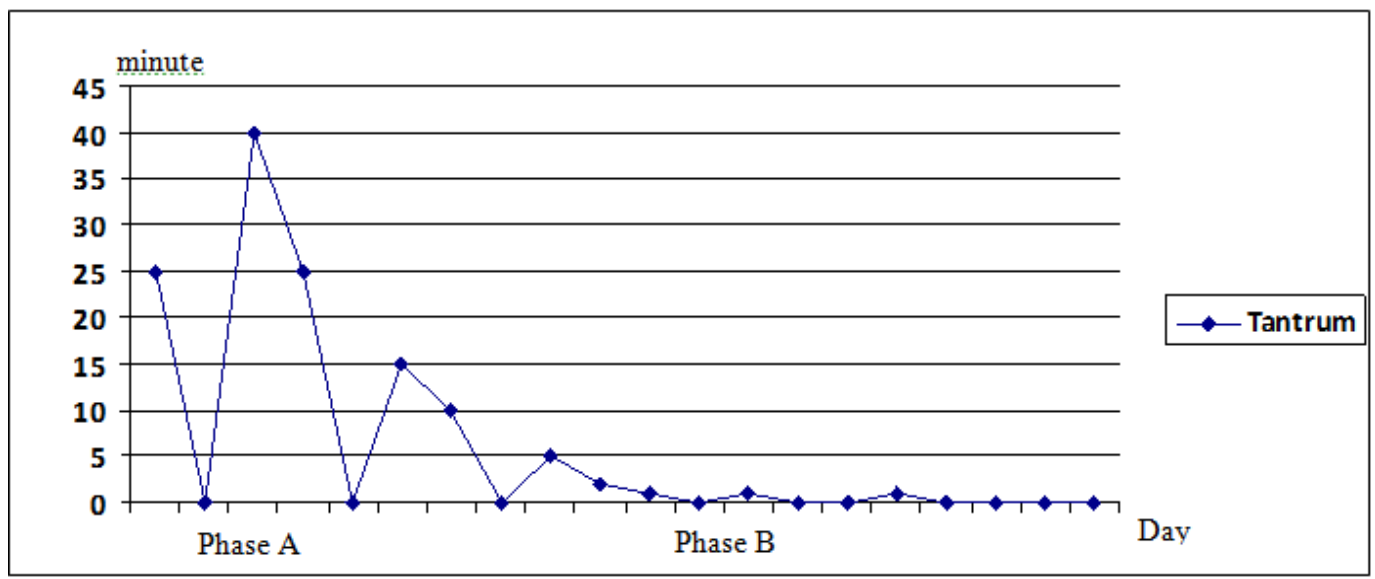

The results from the data collection in the form had demonstrated a reduction in the outburst of such behavior. In the first week of the study carried out without any intervention, the samples were showing a tantrum behavior with a frequency of three times. When intervention (phase B) was carried out, there was a reduction in the outburst of tantrum behavior. In the first week of the intervention period, there were four incidents of tantrum occurred. In the second week of the intervention, the incidents of tantrums were reduced to two events, whereas the tantrum behavior is further reduced to only one incident in the last week of the study.

The analysis was presented in Graph 1 for a clearer view. The overall of the studies have proven that indeed the social story is the best way to change the behavior of someone with autism tantrum. The findings are in line with the opinion of the study by Shari, Brenda \& Judith (1998) whom conducted a study on autistic person who suffered mental problem situations in which the use of pictorial medium, symbols and daily routine schedule posted on social story set can reduce symptoms of tantrum onto their sample and a formation of a better daily routine. Similarly, the findings by Rahmah (2010) which states that by using visuals and media, the autistic learners could increase their level of acquiring knowledge as a result of their lacking in communication skills. According to Sri, Endang, and Yang (2012), an autistic student is no longer throwing tantrum when his nails are cut after the intervention by social custom in the story. He added that a visualized social story given to the autistic student repeatedly daily will also enhance his imagination and strive to show the behavior shown in the intervention.

\section{CONCLUSION AND SUGGESTIONS}

In conclusion, overall the use of social stories technique is effective to change the tantrum behavior on the studied sample. The usage of social stories technique can be applied as an alternative technique to understand the autistic student in any misconduct issue they do thus able to reduce or eliminate negative behaviors.

According to Horner et al. (2002), any intervention that was implemented is not only able to reduce the negative behaviors of autism but also is able to almost completely eliminate the behavior. Autistic students are those who are unique. As an educator, we should use the knowledge and skills that we have to shape the behavior of these students so that they can adapt to the norms of society without creating any social conflict.

As an initiative to the continuity of this study, an indirect monitoring will be continuously to be conducted on the samples of this study to ensure that the tantrum behavior is believed to be eliminated completely. For additional recommendations, social stories can also be innovated in the form of animation along with multimedia applications in the future. We wish to those who were involved in the autism group not to give up continuing to seek diversification to change any negative behaviors, for the benefit of these special people.

\section{REFERENCES}

Adriana, S, G. (2007). Memahami spektrum autistik secara holistik. Makara, Sosial Humaniora, 11(2), 87-99

Aini, A. N., \& Hanifah, N.A. (2015). Tahap pengetahuan guru pendidikan khas apabila mengurus tingkah laku murid bermasalah pembelajaran. Asia Pacific Journal Educators and Education, 30(1), 73-88.

Autism Society of America. (2006). Defining Autism. Receive from http://www.autismsociety.org

Chan, J. M., \& O'Reilly, M. F. (2008). A Social Stories $^{\mathrm{TM}}$ intervention package for students with autism in inclusive classroom settings. Journal of applied behavior analysis, 41(3), 405-409. 
Gray, C. A. (1995). Teaching children with autism to read social situations. In K.A. Quill (Ed.). Teaching Children With Autism. New York: Delmar

Horner, R., Carr, E., Strain, P., Todd, A., \& Reed (2002). Problem behavior interventions for Young children with autism. Journal of Autism and Developmental Disorder. 32(5), 423-446

Liew, P. Y., \& Ali, M. M. (2008). Amalan program intervensi awal kanak-kanak autistik mengikut perspektif ibu bapa. Jurnal Pendidikan Malaysia, $33,19-33$.

Michael, M. (2003). In search of the elusive ADDIE Model. http://iptde. boisestate. edu / filedepository. nsf / bf2ab0f47ba5dd785256499006b15a4 / 693b43c6386 707fc872578150059c1f3 / \$file / molenda_03.pdf

Noraini, I. (2010). Penyelidikan dalam pendidikan. Kuala Lumpur: McGraw Hill (Malaysia) Sdn Bhd

Nurfarhana, S. R., \& Rahim, N. A. (2015). Penerapan elemen penceritaan dalam teknik pembelajaran kanak-kanak sindrom asperger. Journal of Business and Social Development, 3(1), 76-87

Rafiza., \& Maryam. (2013). Pembinaan media pengajaran berasaskan multimedia di kalangan guru ICTL. Jurnal Kurikulum dan Pengajaran Asia Pasifik, 1(2), 20-31

Rahmah. (2010). Strategi pembelajaran untuk mengatasi perilaku tantrum pada anak autistik. Jurnal Ilmiah Ilmu Pendidikan, 10(2), 1-10

Rubina, L., \& Kripa, G. (2011). Children with autism spectrum disorders social stories and self management of behavior. British Journal of Educational Research, 1(1), 36-48

Saadah, S., Salwan, S,. \& Roslee, A. (2008). Kaedah menangani kanak-kanak bermasalah tingkah laku. Seminar Kaunseling Keluarga 2008. Universiti Teknologi Malaysia, hlm. 90-96

Shari, B., \& Judith. (1998). The use of social stories to reduce precursors to tantrum behavior in a student with autism. Article in Focus On Autism and Others Developmental Disabilities, 13(1),176-182

Sri, N. Y., Endang, W., \& Yang, R. (2012). Efek sensory story terhadap penurunan perilaku temper tantrum pada anak autis dengan kesulitan modulasi sensorik. Kajian Ilmiah Psikologi, 2(1), 234-238

Suppiah, N., Ramlah, J., \& Abdul, A. A. S. (2008). Psikologi pendidikan : Siri Pendidikan Guru. Shah Alam : Exford Fajar Sdn Bhd

Thomas. (2005). Behavior management : Application for teachers $4^{\text {th }}$ edition. United States: Pearson Education
Wendy, M., Mark, F. O., Natasha, B., Jeff, S., \& Guilio, E. L. (2007). A review of onterventions to reduce challenging behavior in school settings for students with autism spectrum disorders. Research in Autism Spectrum Disorders. 229-24 